\title{
Assessing Sustainable Rural Community Tourism Using the AHP and TOPSIS Approaches under Fuzzy Environment
}

\author{
M. Mujiya Ulkhaq, Pradita Y. Akshinta, Rizal L. Nartadhi and Susatyo Nugroho W. P. \\ Department of Industrial Engineering, Diponegoro University, Semarang 50275, Indonesia
}

\begin{abstract}
Tourism is currently a sector that is growing into an important and significant world activity. The development of an area where the tourist destination located in affects the growth of the tourism. In addition, the success of tourist destinations are influenced by their relative competitiveness; hence, they do compete each other to offer the best service to satisfy their customers. Rural tourism in Indonesia is believed as emerging business since there are abundant sites located in rural area that offers fascinating attractions to the visitors. This study aims to evaluate the rural tourism using sustainable indicators, namely, service quality, facilities, management system, and outcome. A combination of fuzzy AHP and TOPSIS are employed to select five rural tourism in Central Java Province. Result shows that service quality is considered as the most important attribute with weight of $28.6 \%$, while Dieng is named for the excellent rural tourism. This finding might offer the service providers with valuable insights into the attribute that reflects customers' perceptions about rural tourism; also to position their services based on their competitors.
\end{abstract}

\section{Introduction}

Over the past decade, the convention industry has continued to grow on a global and regional basis. It is a multiservice industry that delivers huge benefits both directly and indirectly in various area including tourism, convention center, accommodations and transportation, restaurants, entertainment, communication, trading, and many more. It also has been recognized for its valuable economic contribution to tourism destinations and its substantial growth potential [1].

Tourism, as a part of convention industry, is one of the largest and fastest growing industries in the world [2]. It is commonly believed to be a viable means of raising the economic activity of such areas. Furthermore, the development of a tourism industry is widely considered to promote the destination's image, enabling the area to achieve other goals, such as business recruitment and retention [3].

According to the World Travel and Tourism Council, in 2014, tourism industry has total contribution to world's GDP of USD 7,580.9 billion-it is expected to grow more than $50 \%$ in 2025 - and to employment of 276,84 it is expected to grow about $30 \%$ in 2025 [4]. In Indonesia, total number of foreign tourist arrivals in 2014 was 9.44 million, up $7.19 \%$ from the preceding year, meaning that the government target of welcoming 9.3 million foreign tourists last year was achieved [5]. Given the expected growth of tourism, there is a great optimism for rural tourism. Numerous researchers have acknowledged tourism as a potential economic development tool, particularly for rural communities [6]. It is progressively being used as a development strategy to improve the social and economic well-being of rural areas.

Rural tourism encompasses a huge range of activities and interests in farms, nature, adventure, sports, health, education, arts, and heritage taking place in countryside as a multi-faceted activity rather than farm-based tourism only [7]. Reference [8] further broaden the concept of rural tourism to include living history of countryside such as rural custom and folklore, local and family traditions, values, beliefs, and common heritage.

Rural tourism in Indonesia holds great potential in terms of sustainable rural development. Sustainable development for community tourism should intend to improve the residents' quality of life by optimizing local economic benefits, protecting the natural and built environment, as well as providing a high-quality experience for visitors [9], [10]. It should both provide a long-term economic linkage between destination communities and industries [11], and also minimize the negative effects of tourism on the natural environment and improve the socio-cultural well-being of the destination communities as well. It is getting increased recognition as a rural economic development tool. The government initiatives have sought to boost tourism as an economic substitute for traditional rural economic activities.

Rural tourism in Indonesia is quite emerging since the rural population is about $47 \%$ of total population in 2014 [12] and $31.5 \%$ of total land is agriculture [13]. Consequently, there are abundant tourist destinations located in rural area that embrace neighborhoods community to attract the visitors. This study aims to select the best sustainable rural community tourism in Central Java 
Province. It may provide some insights to the officer or supervisor of the rural tourism on how patrons rate the rural tourism; hence enabling the officers to position their businesses based on their competitors and to discover the dimensions of sustainable rural community tourism that they have to improve.

This study utilized the combination of fuzzy analytic hierarchy process (AHP) and fuzzy technique for order performance by similarity to ideal solution (TOPSIS) to pursue the objective of the research. To be simple, the fuzzy AHP and TOPSIS approach extends the AHP and TOPSIS [14], [15] by combining it with the fuzzy set theory [16]. Despite of the advantages as seeking consistency and allowing decision makers to structure complex problems in the form of a hierarchy levels, AHP and TOPSIS has been criticized for its inability to handle the ambiguity of the concepts that are associated with human being's subjective judgment which are represented as precise numbers. However, in real life situations, the linguistic assessment of perceptions are fuzzy. Hence, it is more reasonable to represent it in terms to give interval judgments rather than fixed value judgments. The combination of fuzzy AHP and TOPSIS is widely used in the researches; see for example [17]-[19].

\section{Research design}

In this study, the attributes for evaluating sustainable rural community tourism were determined as four main attributes, i.e. service quality, facility, management system, and outcome. The attributes and their sub-attributes are based on research by [20]. However, they had been slightly modified since this study was conducted in Indonesia, especially in Central Java Province, which has different characteristics than the original research.

The first main attribute is service quality (SQ), which is actually an abstract construct that is difficult to define and measure, since the nature of the service is intangible, simultaneous, and heterogeneous. Despite of numerous researches that are studied about how to measure the service quality, there is no general agreement with regard to the content of its dimensions [21]. In this study, it does not utilize the dimensions of service quality used by several researchers, for example [22], [23], since the dimensions are developed in the hospitality service, such as restaurants, hotels, banking, health cares, etc., besides, the sub-attributes that are used in this study are accessibility (SQ1) and convenience (SQ2). The first can be defined as the ability for visitors to access the site location; it can be measured with the provision of site homepage, guidebook and map, and directional sign to the location within let say five kilometers. The second can be measured by ratio of householders who have checklists for bedding and able to pay using credit card.

The second main attribute is facilities (F), which consists of three sub-attributes: accommodations (F1), subsidiary facilities (F2), and environment (F3). Accommodation is measured by the ratio of rooms isolated from host family house, the ratio of rooms with flush toilet, and the ratio of rooms with shower bath. Subsidiary facilities mean meeting room with about a 20-person capacity and parking lots that hold over let say 20 cars. Environment can be measured by refuse disposal system in their community.

The third main attribute is management system (MS), which consists of four sub-attributes: community planning (MS1), collaborated community business (MS2), community management (MS3), and tourism business (MS4). Community planning can be divided into longterm community plan for last three years, fund-raising in their community, and amount of expert consultation for developing tourism. Collaborated com-munity business holds four criteria, i.e. community festival, ratio of householders with tourism management diary, value-added processing businesses in their community, and internet sales for their own products in their community. Community management can measured by minutes and account book for community council meetings, propaganda within last three years, organizing and participating in local tourism development council, and enacting community agreements. The last sub-attribute, tourism business, comprises four criteria, i.e. ratio of householders' participating in community tourism business, full-time worker to manage their tourism business, visitors' insurance, and constructing customer database.

The last attribute is outcomes $(\mathrm{O})$, which comprises of two sub-attributes: satisfaction $(\mathrm{O} 1)$ and income total sales (O2). Satisfaction represents residents' satisfaction and visitors' satisfaction. Income and total sales means increasing rate of a number of visitors, increasing rate of direct sales, number of one company one village linkage, and ratio of equity capital per government assistance.

The objective of this study is set to find out the best sustainable rural community tourism in Central Java Province, Indonesia. Bandungan, Baturaden, Dieng, Kopeng, and Sidomukti are selected because they could be considered as leading tourist attractions in Central Java Province. The map of those five is depicted in Fig. 1. Visitors can learn and explore the nature, the panoramic beauty of the scenery, as well as interact with the residents who are living there.

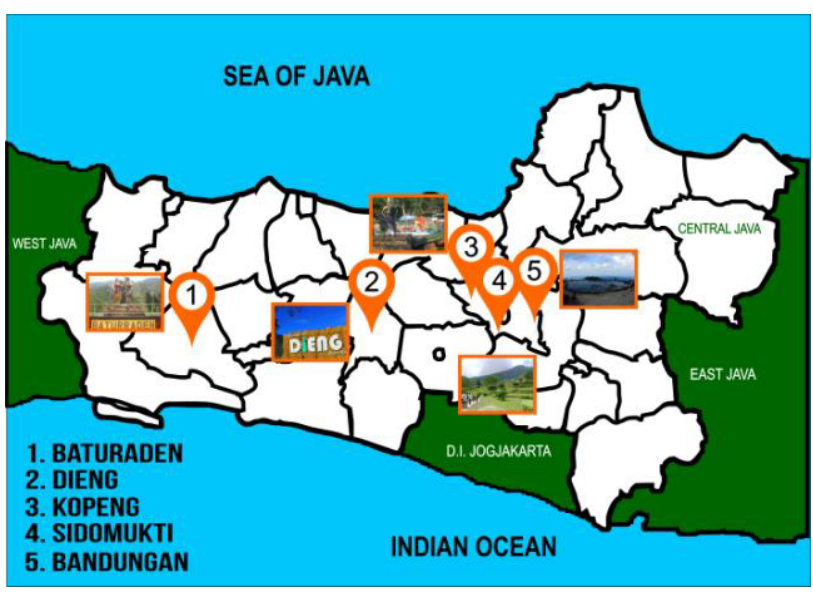

Figure 1. Map of objects of the study.

Bandungan is a potential tourist destination, which is located on the mountain slope at the Ungaran Mountain. It has a very beautiful natural scenery. Numerous distinctive vegetables, fresh fruits, and lovely flowers can be 
found along the way. Bandungan is a paradise for nature lovers; there are many wonderful rides and challenging natures. Coffe café, spa, traditional temple called Gedong Songo, camp of rose, flower markets, and Rawa Pening, a beautiful tiny-lake, can be discovered in Bandungan. In addition, its beautiful panorama is usually exploited by photographers, or even by a couple for his/her wedding proposal's photoshoots.

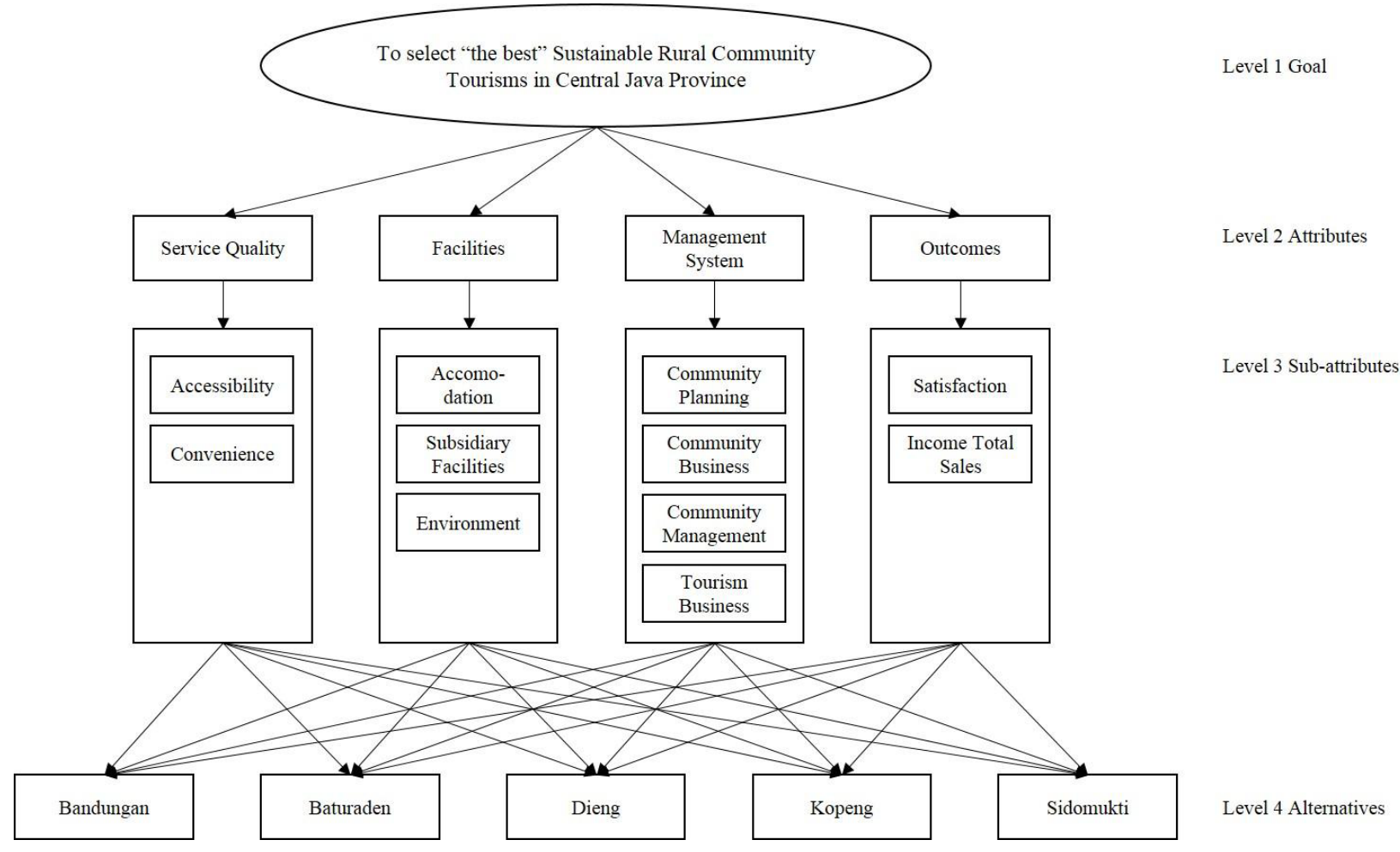

Figure 2. The evaluation framework of the sustainable rural community tourism model.

The next site is Baturaden. Five of eleven tourist destinations in Banyumas are located in Baturaden. It becomes a leading tourist district area in Banyumas since it is frequently visited by domestic or foreign visitors. It has been known as a tourist resort with a variety of exciting attractions with complete facilities supporting it. A plateau of Dieng is located at the northeast Banjarnegara, and could be regarded as the number two tourist destination in Central Java after Borobudur. There are Arjuna and Ghatotkacha Complex - two major characters of puppetry in Java legend, Bima temple, Dwarawati and Jalatunda wells, archeological museum, Balekambang lake, Merdada tiny-lake, Sikidang Candradimuka, and Sileri craters, as well as Bitingan hot spring waters. Located at the altitude of 2,093 meters above the sea level, Dieng plateau has fresh air temperature range from 15 to 20 degrees Celsius, and sometimes foggy when the weather is cloudy.

Kopeng is located in the Semarang area. It has several ideal locations that could be used by family as a recreation spot, camp, meeting, and seminar held by government or private institution. It also provides a camping ground for outbound activity. There are lodging of Kartika Travel, Songo Bannerman camping ground, and Mount Merbabu climbing spot. It presents gorgeous panorama in countryside combined with the landscape full of beautiful flowers and various fresh vegetables. Sidomukti is also located in the Semarang area precisely in the slope of Ungaran Mountain. Sidomukti nature parks is located at an altitude of 1,200 meters above the sea level. The open-for-public swimming pool is very attractive for visitors since it serves a beautiful view of the mountain. Sidomukti also provides an exciting adrenaline game for visitors with affordable cost.

In order to apply the fuzzy AHP and fuzzy TOPSIS methodology to the prioritizing of attributes for assessing the sustainable rural community tourism, the attributes abovementioned are initially structured into different hierarchy levels. The hierarchy of the decision model is shown in Fig. 2, where the goal is to select the best sustainable rural community tourism in Central Java Province. This hierarchy of attributes is the subject of a pairwise comparison of the methods being used. Data are collected from five experts who are very fond of traveling and have abundant experiences in visiting rural community tourism. The decision makers are asked to compare the elements on a pairwise basis in order to estimate their relative importance in relation to the element at the immediately preceding level, i.e. the attributes. A ninepoint scale questionnaire is used to show the decision makers' judgment between options as equally, moderately, strongly, very strongly, and extremely favourable (or unfavourable).

\section{Fuzzy AHP and fuzzy TOPSIS}

There are various fuzzy AHP methods proposed by numerous authors to handle the comparison matrices. Among them, [24] is widely used due to its implementation simplicity to calculate relative weights. 
A fuzzy number is a special fuzzy set $F=\{(x, \mu \widetilde{A}(x), x \in R)\}$, where $x$ takes values on the real line, $R$ : $-\infty<x<+\infty$ and $\mu \widetilde{A}(x)$ is a continuous mapping from $R$ to the closed interval [0,1]. A triangular fuzzy number denoted as $\tilde{A}=(l, m, u)$, where $l \leq m \leq u$, has the following triangular-type membership function:

$$
\mu \tilde{A}(x)= \begin{cases}\frac{x}{m-l}-\frac{l}{m-l}, & x \in[l, m], \\ \frac{u}{u-m}-\frac{x}{u-m}, & x \in[m, u], \\ 0, & \text { otherwise, }\end{cases}
$$

where $l, m$, and $\mathrm{u}$ are lower, mid, and upper value of the support of $M$ respectively, as well as $m$ is the mid-value of $\tilde{A}$. In this study, first linguistic terms are used to represent the decision makers' assessments, and then triangular fuzzy numbers (TFN) are used for evaluations.

The four-step-procedure is given as follows:

1. Compare the performance score. Linguistic terms are used to indicate the relative strength of each pair of elements in the same hierarchy.

2. Construct the fuzzy comparison matrix $\tilde{A}$.

3. Solve the fuzzy eigenvalue. A fuzzy eigenvalue $\tilde{\lambda}$, is a fuzzy number solution to $\tilde{A} \widetilde{x}=\tilde{\lambda} \widetilde{x}$, where $\tilde{\lambda}_{\max }$ is the largest eigenvalue of $\tilde{A}$ and $\widetilde{x}$ is a non-zero fuzzy vector containing fuzzy number $\tilde{x}_{i}$.

4. The priority weight of each alternative can be obtained by multiplying the matrix of evaluation ratings by the vector of attribute weights and summing over all attributes.

After having weight of each alternative, fuzzy TOPSIS method is being employed. The steps are presented as follows:

1. Compute the fuzzy positive ideal solution (FPIS) and fuzzy negative ideal solution (FNIS) as follows:

$$
\begin{aligned}
& \mathrm{FPIS}=A^{+}=\left(\tilde{v}_{1}^{*}, \tilde{v}_{2}^{*}, \ldots, \tilde{v}_{n}^{*}\right) \\
& \mathrm{FNIS}=A^{-}=\left(\tilde{v}_{1}^{-}, \tilde{v}_{2}^{-}, \ldots, \tilde{v}_{n}^{-}\right)
\end{aligned}
$$

where $\widetilde{v}_{j}^{*}=\max _{i}\left(v_{i j}\right), \widetilde{v}_{j}^{-}=\min _{i}\left(v_{i j}\right), i=1, \ldots, m ; j=1, \ldots$, $n$; and $v_{i j}$ is weighted normalized matrix.

2. Compute the distance of each alternative from FPIS and FNIS $\left(d_{i}^{*}, d_{i}^{-}\right)$:

$$
d_{i}^{*}=\sum_{j=1}^{n} d_{v}\left(\tilde{v}_{i j}, \tilde{v}_{j}^{*}\right) ; d_{i}^{-}=\sum_{j=1}^{n} d_{v}\left(\tilde{v}_{i j}, \tilde{v}_{j}^{-}\right)
$$

where $d_{v}\left(\tilde{v}_{i j}, \tilde{v}_{j}^{-}\right)$is the distance measurement bet-ween two fuzzy numbers $\widetilde{v}_{i j}$ and $\tilde{v}_{j}^{-}$.

3. Compute the closeness coefficient $\left(C C_{i}\right)$ of each alternative:

$$
C C_{i}=\frac{d_{i}^{-}}{d_{i}^{-}+d_{i}^{+}}
$$

4. Rank the alternatives. In step 3, the different alternatives are ranked according to the closeness coefficient $C C_{i}$ in decreasing order. The best alternative is closest to the FPIS and farthest from the FNIS.

\section{Case study}

The following is the application of fuzzy AHP and fuzzy TOPSIS to evaluate the sustainable rural community tourism in Central Java Province, Indonesia. The methods were employed based on the aforementioned attributes. First, the decision makers filled the pairwise comparison to express their preferences between the alternatives, attributes, and sub-attributes in a nine-point scale questionnaire. Their answers were then transformed into triangular fuzzy numbers.

The results of application of fuzzy AHP and fuzzy TOPSIS are alternative priority weights (APW) indicated the important of attributes of sustainable rural community tourism and the alternatives' priority referred to each attribute. The results can be seen in Table 1 .

As the result from Table 1, service quality is regarded as the most important attribute with $28.9 \%$. The next is management system with $24.4 \%$, facilities with $24.3 \%$, and the least important is outcome with $22.7 \%$. This seems that the decision makers viewed the service given by the tourist destination as the main factors that have to manage to win a competition among their competitors.

The weights for sub-attributes of service quality are given as follows. Accessibility (SQ1) is believed to be the most important with the weight of 0.856 , while convenience (SQ2) is considered the least important with $14.4 \%$. The tourist destination with the best performance on service quality attribute is Dieng. For facilities attribute, environment (F3) is considered as the most important sub- attribute with weight of $34.6 \%$. The next is accommodation (F1) with $33.8 \%$ and the last is subsidiary facilities (F2) with $31.5 \%$. Sidomukti is believed to be the best rural tourism in accordance with facilities attribute by $21.6 \%$.

The third attribute, i.e. management system, the subattribute which is thought to be the most important is community planning (MS1) with weight of $25.9 \%$. Tourism business (MS4) and community management (MS3) are believed to be the second and third most important with weight of $25.6 \%$ and $24.6 \%$. The least important sub-attribute is collaborated community business (MS2) with $24.2 \%$. Dieng is regarded to be the best rural tourism in line with management system attribute.

The last attribute, i.e. outcome, satisfaction (O1) is considered as the most important sub-attribute with weight of $50.9 \%$, and the other sub-attribute, i.e. income and total sales (O2) has weight of $49.1 \%$. The decision makers chose Dieng to be the best rural tourism in performing outcome attribute.

Finally, the sustainable rural community tourism also were compared using the fuzzy TOPSIS. According to all the calculations, Dieng is considered as the best site with 
the value of relative approximation value versus ideal solution is 0.855. The next is Sidomukti with 0.615, Baturaden with 0.462 , Bandungan with 0.456 , and the last is Kopeng with the value of zero.

Table 1. Summary of APW for each attribute.

\begin{tabular}{|l|c|c|l|l|l|}
\hline \multicolumn{1}{|c|}{ SQ } & SQ1 & SQ2 & & & APW \\
\hline Weight & 0.856 & 0.144 & & & 0.286 \\
\hline Bandungan & 0.200 & 0.203 & & & 0.201 \\
\hline Baturaden & 0.201 & 0.210 & & & 0.203 \\
\hline Dieng & 0.210 & 0.198 & & & 0.208 \\
\hline Kopeng & 0.195 & 0.180 & & & 0.193 \\
\hline Sidomukti & 0.193 & 0.210 & & & 0.196 \\
\hline \multicolumn{1}{|c|}{ F } & F1 & F2 & F3 & & APW \\
\hline Weight & 0.338 & 0.315 & 0.346 & & 0.243 \\
\hline Bandungan & 0.207 & 0.206 & 0.178 & & 0.197 \\
\hline Baturaden & 0.195 & 0.202 & 0.215 & & 0.204 \\
\hline Dieng & 0.207 & 0.200 & 0.188 & & 0.198 \\
\hline Kopeng & 0.196 & 0.188 & 0.201 & & 0.195 \\
\hline Sidomukti & 0.195 & 0.204 & 0.218 & & 0.205 \\
\hline \multicolumn{1}{|c|}{ MS } & MS1 & MS2 & MS3 & MS4 & APW \\
\hline Weight & 0.259 & 0.242 & 0.246 & 0.256 & 0.244 \\
\hline Bandungan & 0.204 & 0.198 & 0.206 & 0.197 & 0.202 \\
\hline Baturaden & 0.198 & 0.206 & 0.191 & 0.181 & 0.195 \\
\hline Dieng & 0.206 & 0.218 & 0.208 & 0.231 & 0.216 \\
\hline Kopeng & 0.191 & 0.165 & 0.189 & 0.185 & 0.183 \\
\hline Sidomukti & 0.201 & 0.213 & 0.206 & 0.205 & 0.207 \\
\hline \multicolumn{1}{|c|}{ O } & O1 & O2 & & & APW \\
\hline Weight & 0.509 & 0.491 & & & 0.277 \\
\hline Bandungan & 0.184 & 0.202 & & & 0.193 \\
\hline Baturaden & 0.196 & 0.207 & & & 0.201 \\
\hline Dieng & 0.224 & 0.198 & & & 0.211 \\
\hline Kopeng & 0.196 & 0.183 & & & 0.190 \\
\hline Sidomukti & 0.200 & 0.209 & & & 0.205 \\
\hline
\end{tabular}

\section{Conclusion and future research}

The purpose of this study is to assess the performance of sustainable rural community tourism in Central Java Province, Indonesia, based on aforementioned attributes and sub-attributes. The result of this study which is shown in Table 1 is indicated that service quality is considered as the most important attribute with weight of $28.6 \%$ and the least important attribute is outcome. It shows that service providers of rural tourism should focus more on service quality to perform satisfactory service.

The ranking of rural tourism based on calculation is Dieng for the first rank, Sidomukti for the second, Baturaden for the third, Bandungan for the fourth, and Kopeng for the last. It does not mean that Dieng provides a gorgeous service than the others. In fact, other rural tourism should improve their service considering with these attributes. This finding can provide the officers of the rural tourism with valuable insights into the attribute that reflects customers' perceptions about rural tourism; also to position their services based on their competitors.

There can be other method to evaluate the service of sustainable rural community tourism. It is highly recommended to utilize the other tools such as analytic network process [25] when the attributes are assumed correlates each other. Further research may be the application of these methods to evaluate other sustainable rural community tourism. Validating the scale in other site locations is an interesting area to be pursued.

\section{References}

1. L. Dwyer, Economic contribution of convention tourism: conceptual and empirical issues (Haworth, New York, 2002).

2. D.L. Edgell, International tourism policy (Van Norstrand Reinhold, New York, 1990).

3. D.L. Barkley, Economic adaptation: alternatives for non-metropolitan areas. The potential for tourism development in non-metropolitan areas (Westview Press, San Francisco, 1993).

4. World Travel and Tourism Council, Travel and tourism: economic, https://www.wttc.org//media/files/reports/economic\%20impact\%20researc h/regional\%202015/world2015.pdf (2016).

5. Statistics Indonesia, Tourism in Indonesia: record high number of foreign visitor arrivals, http://www.indonesia-investments.com/news/newscolumns/tourism-in-indonesia-record-high-numberof-foreign-visitor-arrivals/item5280.

6. G. Prosser, Regional tourism research: a scoping study (Centre for Regional Tourism Research, 2000).

7. B. Bramwell, B. Lane, Rural tourism and sustainable rural development (Channel View, London, 1994).

8. J. Pedford, Seeing is believing: the role of living history in marketing local heritage (Hisarlink Press, Enfield Lock, 1996).

9. D.B. Park, Y.S. Yoon, Tourism Manag. 30 (2009).

10. D.B. Park, Y.S. Yoon, M. Lee, J. Econ. Geo. Soc. 11, 4 (2008).

11. H.C. Choi, E. Sirakaya, Tourism Manag. 27 (2006).

12. World Bank, Rural population, http://data. worldbank.org/indicator/SP.RUR.TOTL.ZS (2016).

13. World Bank, Agricultural land (\% of land area), http://data.worldbank.org/indicator/AG.LND.AGRI. ZS (2016).

14. T.L. Saaty, The analytic hierarchy process: planning, priority setting (McGraw-Hill International Book, Co., New York, 1980).

15. C. Hwang, K. Yoon, Multiple attribute decision making: methods and application (Springer, New York, 1981).

16. L.A. Zadeh, Info. Cont. 8 (1965).

17. F.R. Lima-Junior, L.C.R. Carpinetti, Int. J. Prod. Econ, 174 (2016).

18. Y.H. He, L.B. Wang, Z.Z. He, M. Xie, Eng. App. Artif. Intelligence, 47 (2016).

19. D.A. Wood, J. Nat. Gas Sci. Eng, 28 (2016).

20. D.B. Park, Y.S. Yoon, Int. J. Tourism Res. 13 (2011)

21. M. K. Brady, J.J. Cronin, J. Marketing, 65, 3 (2001).

22. A. Parasuraman, V.A. Zeithaml, L.L. Berry, J. Retailing, 64, 1 (1988).

23. J.J. Cronin, S.A. Taylor, J. Marketing, 56 (1992).

24. D.Y. Chang, Eur. J. Oper. Res. 95 (1996).

25. T.L. Saaty, The analytic network process: decision making with dependence and feedback (RWS Publications, Pittsburgh, 1996). 